\title{
IMPACTS OF BLACK FEMINISM ON THE PROMOTION AND PROTECTION OF BLACK WOMEN'S RIGHTS
}

\section{IMPACTOS DO FEMINISMO NEGRO NA PROMOÇÃO E PROTEÇÃO DOS DIREITOS DAS MULHERES NEGRAS}

\author{
Rafaelle Franchini ${ }^{1}$ \\ Caio Eduardo Costa Cazelatto ${ }^{2}$ \\ Valéria Silva Galdino Cardin ${ }^{3}$
}

\begin{abstract}
This article analyzed, through bibliographic review, the social movement of feminism as an instrument of protection and promotion of black women's rights. To this end, the historical development of the feminist movement was investigated, with a focus on European countries and the United States of America, as well as the legal developments and achievements obtained by Brazilian black women from the Carta das Mulheres aos Constituintes or Letter of Women to the Constituents. It explored the fundamental rights that were claimed and achieved by the feminist movement for black women. Thus, it was found that the trajectory of black women is strongly marked by the reflexes that slavery and social marginalization have historically brought to this vulnerable segment, as it was also observed that the social movement of black feminism ended up not effectively representing the claims of black women, who, for the most part, are still related to the consequences of the period of slavery, such as low or no education, underemployment, victims of violence against women, among others.
\end{abstract}

KEYWORDS: Fundamental rights; Black feminism; Feminist Social Movement.

RESUMO: O presente artigo analisou, por meio da revisão bibliográfica, o movimento social do feminismo como um instrumento de proteção e promoção dos direitos das mulheres negras. Para isso, investigou-se o desenvolvimento histórico do movimento feminista com enfoque nos países europeus e nos Estados Unidos da América, bem como verificaram-se os desdobramentos jurídicos e as conquistas obtidas pelas mulheres negras a partir da Carta das Mulheres aos Constituintes. Da mesma forma,

\footnotetext{
${ }^{1}$ Pós-graduanda em Direito Civil pela Universidade Estadual de Londrina (UEL); Bacharela em Direito pela Universidade Estadual de Maringá (UEM); Pesquisadora no grupo de pesquisa "Direitos da Personalidade e seu alcance na contemporaneidade" da Universidade Cesumar (Unicesumar). E-mail: rafa_franchini@hotmail.com.

2 Doutorando em Direito pela Universidade Federal da Bahia (UFBA); Mestre em Ciências Jurídicas pela Universidade Cesumar (Unicesumar). Bacharel em Direito pela Universidade Estadual de Maringá (UEM). Pesquisador no Centro de Investigação Jurídico-Econômica (CIJE) da Faculdade de Direito da Universidade do Porto (FDUP). Advogado. E-mail: caio.cazelatto@hotmail.com.

${ }^{3}$ Pós-Doutora em Direito pela Universidade de Lisboa. Doutora e Mestre em Direito das Relações Sociais pela Pontifícia Universidade Católica de São Paulo. Docente da Universidade Estadual de Maringá e no Programa de Pós-Graduação de Doutorado e Mestrado em Ciências Jurídicas da Universidade Cesumar. Pesquisadora e Bolsista Produtividade ICETI. Advogada no Paraná. E-mail: valeria@galdino.adv.br.
} 
exploraram-se os direitos fundamentais enquanto reivindicações do movimento feminismo para as mulheres negras. Com a pesquisa, constatou-se que a trajetória destas é fortemente marcada pelos reflexos que a escravidão e marginalização social acarretaram historicamente a esse segmento vulnerável, como também se observou que o movimento social do feminismo negro não representa integral e efetivamente as reivindicações das mulheres negras, que ainda lutam pela superação do predomínio da baixa ou a ausência de grau de escolaridade, subempregos, violência doméstica, dentre outras.

PALAVRAS-CHAVE: Direitos fundamentais; Feminismo negro; Movimento Social Feminista.

\section{INTRODUCTION}

At the end of the 1970s, the first movements in defense of feminism emerged, in view of the struggle of women for social, political and economic equality in relation to the privileged patriarchy of the time. Thus, at first, the movement was initiated by white women, with some kind of education, often intellectual, literate, driving away the movement of poor women, slaves, without any guarantee of human dignity, which embodied the majority of the black female population.

It can be said that black feminism is the struggle of a minority within another minority, due to the historical and social diversity between white and black women. Thus, the division of the feminist social movement is defended with the aim of better meeting the needs of each group, through laws, treaties and international conventions in defense of better living conditions for black women, their recognition as an individual of a society with rights and duties. Thus, the work will research the feminist social movement in its historical context; the consequences arising from the "Women's Letter to Constituents", the struggle for individual, political, social and economic rights; black feminism; the combat against racism and violence and fundamental rights, advances and challenges.

For the research, the logical-deductive method was used, in order to comprehend the general context and understand the aspects of the particular situations. For this, we composed our work in an interdisciplinary manner using 
bibliographic research in books, legislation, jurisprudence, reports, articles, theses and online documents, in the areas of Law, Sociology and Psychology.

\section{THE FEMINIST SOCIAL MOVEMENT IN ITS HISTORICAL CONTEXT}

The feminist struggle became predominant as of 1970, in a movement of women fighting for basic conditions such as housing, health, food, decent working conditions and day care centers in factories and universities, as well as other issues. These claims took place before a military dictatorial government in Brazil, in power since 1964.

In this political context, there was a harsh repression against the leftist regime, with deaths, torture, strong censorship in the media, removal of political parties and the recurrent threat to fundamental rights and free expression, with the aim of strengthening the power of the military. In this scenario, any political demonstration was seen as a threat to national security (CORREAA, 2001, p. 16-18).

It was through the support of the Church, especially the Catholic church, and the Communist Party, that the demonstrations began to form academically and professionally. With the 1964 military coup, many young people joined the resistance and the armed struggle, including many militant women together with their fellow fighters. Due to these conflicts, many couples fled Brazil to countries in Europe, mainly to France to begin a new life. In this new European scenario, the majority of middleclass women began to notice that, far from their traditional families, bourgeois parents and maids who did all the domestic tasks, their husbands remained accommodated and not concerned about sharing household chores, making the social, economic and political difference between men and women rather evident (GONÇALVES, 2009, p. 2).

It's important to understand the transforming, critical and emancipatory context of the movement that, despite all its restrictions and impediments, due to the cultural and historical characteristics of the time, managed to highlight the role of women as a thinking being and a transforming political agent of its space, as Cynthia Andersen Sarti (2004, p. 2) explains: 
It is argued that, although influenced by European and North American experiences, the beginning of Brazilian feminism of the 1970s was significantly marked by the challenge to the political order instituted in the country since the military coup of 1964. An expressive part of the feminist groups was connected to organizations of Marxist influence, clandestine at the time, and strongly committed to the opposition to the military dictatorship, which imprinted its own characteristics on the movement (free translation). ${ }^{4}$

The feminist movement began to question the functioning of society and the order of the day was "transformation", because they believed in the change of mental structures consolidated by the patriarchy. This political affinity through left-wing organizations and experiences with French feminism were essential in enabling the development of feminist though the Brazilian exiled women. Feminist activities in Paris served as an indispensable theoretical reference for national debate groups (GONÇALVES, 2009, p. 2-3).

In the period of the last military governments, the situation was milder and less conflicting. Brazil was constantly changing, seeking to modernize labor relations and improve education. Still, in an exclusionary way, women also began to benefit from social transformations. New affective and sexual behaviors emerged, mainly due to access to psychological therapies and psychoanalysis, as well as increased access to contraceptives, which enabled and assisted with family planning. In 1970, Brazil sold about 6.8 million packs of contraceptive pills and in 1980 this number rose to 40,9 million, representing an accelerated growing market (PEDRO, 2003, p. 243).

In these circumstances, 1975 was declared the International Year of Women by the United Nations (UN) providing a scenario that would allow the visibility of feminist demands, where the 1st World Women's Conference took place under the motto "Equality, Development and Peace", with the central theme "The elimination of discrimination against women and their social advancement". The Conference approved an action plan to put in place the guidelines between 1976 and 1985

\footnotetext{
4 Original text: "Argumenta-se que, embora influenciado pelas experiências europeias e norteamericana, o início do feminismo brasileiro dos anos 1970 foi significativamente marcado pela contestação à ordem política instituída no país, desde o golpe militar de 1964. Uma parte expressiva dos grupos feministas estava articulada a organizações de influência marxista, clandestinas à época, e fortemente comprometida com a oposição à ditadura militar, o que imprimiu ao movimento características próprias."
} 
(PEDRO, 2003, p. 254-255) for governments and the international community. These events allowed for the expansion of concepts and fights that operated underground. After 1975, the first newspaper launched and directed by women under the name Brasil Mulher was published by Sociedade Brasil Mulher, with 16 (sixteen) regular editions and 4 (four) extras, with publications up until 1980. The second one, called Nós Mulheres, was published by the Women's Association, had eight (8) editions that circulated from 1976 to 1978 (PEDRO, 2003, p. 254).

In this sense, for Rosalina de Santa Cruz Leite (2003):

The fact that they were linked to an association already shows that these newspapers were instruments of dissemination of an organized women's collectives and, as such, gave coverage to issues not published by the official press, at a time of strong political censorship, reflecting the political thought of feminist militancy (free translation). ${ }^{5}$

At first, this whole articulation was called the "women's movement", but it expanded and gained strength through printed means that made it possible to approach the lower layers of society, constituting a movement with several social classes. Women, thus, wanted to study and discuss gender issues, question the role of the Catholic Church, study the principles of left-wing groups and disturb the authoritarian and patriarchal regime (SARTI, 2004, p. 5).

The next decades were marked by the mobilization of women and groups that fought for the value of women's work, their political, reproductive and sexual rights. Feminists began discussions on gender, consolidating the understanding that the "masculine" and the "feminine" are not defined by the characteristics of each sex, due to the fact that they are socially constructed concepts. They correspond to a set of meanings, symbols and attributes that each society constructs, through its historical and social characteristics, to differentiate each of the sexes (OLIVEIRA, 2006, p. 5).

Educated and interested, women began to defend their rights internationally and demand that issues such as rape, domestic violence and sexual harassment be

\footnotetext{
${ }^{5}$ Original text: "O fato de estarem vinculados a uma associação já mostra que esses jornais eram instrumentos de divulgação de coletivos de mulheres organizadas e, como tal, davam cobertura a assuntos não veiculados pela imprensa oficial, na época sob forte censura política, refletindo o pensamento político da militância feminista."
} 
addressed and guidelines put in place for their dignity, access to education and professionalization, sexual health, reproductive rights, abortion and the fight against any discrimination. The feminist movement sought the re-appropriation of the female body, in order to counter the ideas surrounding it, which framed it in specific spaces and determined functions. Therefore, it was important to recognize the rights they had, a stark contrast from the reality of neglected, to then consolidate and claim the demands and start the necessary fight to conquer such rights.

In view of this, there was the redefinition of the female body and the space it occupies, causing women to place themselves in a different position from the historically pre-shaped one imposed by society. Thus, there was the individual study of the female gender and the social context in which it is inserted, making it imperative to observe the possibilities and deprivations inherent to women, so that the necessary demands, for both society and the State, could emerge as something worth fighting for in this movement.

Women are framed in specific roles, through their specific experiences, which correspond to the strengthening of certain characteristics that are not entirely negative, but that weaken them as an individual. In this aspect, it has become increasingly necessary and relevant for each woman to live her most expressive femininity, discover her body and command it without any kind of patriarchal, sexist and hierarchical imposition. It is essential to leave aside the demand for such behaviors as passivity, motherhood, femininity. Women need a voice to express their opinions and fight for their rights, just like any other human being (BIROLI, 2013, p. 93-94).

As the military dictatorship was coming to an end and the desire, by various groups, for democracy lingered in the country, women began discussions with the purpose of obtaining a more effective response from the State, with the creation of public policies and legislative reforms.

In 1984, the Ministry of Health created the Integral Assistance to Women's Health Program. Prior to the program, the medical field focused only on women's reproductive health, while other complaints were not checked and women were not fully examined. With the consolidation of the project, actions aimed at health promotion 
and prevention measures were expanded, there was an increase in care for cases of cancer, obesity, drugs as well as domestic and sexual violence (RODRIGUES, 2016).

In 1985, the National Council for Women's Rights (CNDM) was created, released by the August 29, 1985, Law n. 7,353 of and regulated by Decree $n$. 6.412/2009. The Council first president to be elected was Ruth Escobar, one of the leaders of the movement, and a great creator of the search for gender equality. The intention of the project was to promote policies aimed at eliminating discrimination against women and ensuring their participation in political, economic and cultural activities in the country. In addition, in 1985, the Commission for Studies on the Rights of Human Reproduction (CEDRH) was created by the Ministry of Health (NACIONAL, 2018).

Years passed and the struggles continued. Back in 1922, the conservative feminist Bertha Lutz founded the Brazilian Federation for Women's Progress (FBPF), which aimed at promoting the education and professionalization of women. She was fundamental in winning the female vote and the struggle for women's political rights (BRASIL, 2015).

At the international level, in 1980 there was the II World Women's Conference under the motto "Education, Employment and Health", held in Copenhagen. And in 1985 there was the III World Conference on Women with the central theme "Future Oriented Strategies for Women's Development until the Year 2000", held in Nairobi. Similarly, in 1995 there was the IV World Conference on Women held in Beijing with the theme "Action for Equality, Development and Peace" (ONU MULHERE BRASIL, $S / A)$.

In 1994, the Inter-American Convention to Prevent, Punish and Eradicate Violence against Women, known as the "Convention of Belém do Pará", was issued by the Brazilian State in 1995. This instrument is of great relevance, as it was the first international treaty protecting women's human rights to recognize violence against women as a widespread problem in society (INTER-AMERICAN COMMISSION ON HUMAN RIGHTS, 1994).

Finally, after the discussions over the years, the public policies developed, the understandings consolidated in the conferences and conventions held, the visibility of 
the State and the incessant permanence of the struggle of women for rights initially denied, it can be evidenced that there was a highlight for it to intend, generate discussions and resolutions through the proposed guidelines.

\subsection{DEVELOPMENTS ARISING FROM THE "LETTER OF WOMEN TO THE CONSTITUENTS", THE FIGHT FOR INDIVIDUAL, POLITICAL, SOCIAL AND ECONOMIC RIGHTS}

Under the direction of sociologist Jacqueline Pitanguy de Romani, and State Representative Ruth Escobar the National Council for Women's Rights, or Conselho Nacional dos Direitos da Mulher (CNDM), was created in 1985 and associated to the Ministry of Justice. The Council was composed of middle-class women, linked to women's movements or politics. Thus, the focus was on the creation of the Campaign "Woman and Constituent" with the slogan "Constituinte Pra Valer Tem Que Ter Palavra De Mulher" or "A Worthy Constituent Must Have A Woman's Word", with the intention of stimulating debates and discussions about women's rights so that they are defended and become substantive law in the Federal Constitution (LIMA, 2016, p. 11-12).

It became urgent to call for a constitution that would take into account women's claims. But for this, it was also necessary to listen to the demands of the lower layers of society. For 20 months, the National Council for Women's Rights asked women across Brazil to send via letters and telegrams, proposals and ideas they would like to see in the Constitution. With the help of jurists, the Council gathered and organized these proposals with the purpose of creating the "Letter of Women to the Constituents", which was delivered in March 1987 to the president of the Constituent Assembly, Deputy Ulysses Guimarães. Due to the pressure of women, around $80 \%$ of the demands in the Letter were included in the Federal Constitution of 1988 (WELLE, 2018).

Within the House of Representatives (even with a consolidated women's caucus, composed of the CNDM, the women's movement, feminist activists and 26 (twenty-six) elected deputies) some congressmen tried to belittle, diminish the movement and referred to the participants as "women in lipstick". Therefore, the 
women decided to assume the title "lipstick lobby" in an ironic way and began to use this name in materials, campaigns and publications (WELLE, 2018).

As demonstrated, the feminist struggle was fundamental for the concretization of female representation in politics. The claims were based on an egalitarian political system, where women could be free subjects to argue, question, study, work, transit, regardless of space, before a government that preserved their rights, without prejudice regarding sex, race, color, class, sexual orientation, political or religious creed, physical condition or age (BRASIL, 1987).

Currently, the National Council for Women's Rights is composed of representatives of the civil society and the government, significantly expanding the process of social control over public policies for women. It also integrates the structure of the Ministry of Human Rights and has as one of its duties to support the National Secretariat for Policies for Women with various institutions that are part of the Federal Public Administration and the civil society (CTB, 2017).

The new 1988 Constitution ensured rights that served as the basis for later legislations such as the Maria da Penha Law (Law n. 11,340/2006), which punishes any type of aggression against women that occurs in the domestic and family spheres, for example. In addition it ensured family planning; the right to information on contraceptive methods; It extinguished the Statute of Married Women, which required a husband's authorization for a woman to work; extended maternity leave from 84 (eighty-four) days to 4 (four) months; instituted paternity leave; guaranteed labor and social security rights for domestic workers, with the Constitutional Amendment Draft of Domestic workers in 2012; It guaranteed rural women the right to land ownership and for inmate women the right to breastfeed their children (WELLE, 2018).

\section{THE BLACK FEMINISM}

As already mentioned, in the 1970s the first feminist manifestations in Brazil took place, but only in May of 1888, through the Lei Áurea or the Aurea Law, was slavery abolished. The new law freed about 700,000 slaves in a country with 15 million 
inhabitants (ANDRADE, 2018). This historical fact is decisive for the understanding of black feminism and its demands which differ from the feminist's initially portrayed.

In this colonial period, women worked as slaves on farms, on the streets, as prostitutes, cooks, saleswomen, in other words, voiceless women, who were never heard, who never had any rights guaranteed and suddenly came across a scenario where white women disseminated and praised feminism, in search of rights similar to the men at that time. These realities are contradictory, because when one approaches the myth of female frailty, which justified the paternalistic protection of men over women, one questions why black women have never been seen within this fragile profile (CARNEIRO, 2018).

Evidently, these women, who never had any guaranteed rights, did not fit into the initial feminist educated white Western group. In addition to suffering gender discrimination, black women also suffered racism and discrimination from a society that saw them as not having feelings or rights. They were treated as objects, in a violated and marginalized culture, treated as a primitive thing. They were bought so they could work in the fields and perform domestic services, supply the carnal desires of their masters and meet the demands of the fragile "sinhazinhas", the daughters of powerful landowners (CARNEIRO, 2018).

All these factors indicate that there wasn't only a struggle for economic, social and political equality between genders, but an anti-racist struggle too. Thus, racism becomes a factor tar must be fought, often times in a veiled and discreet way, making this fight even more difficult. These issues also changed the perception of gender, becoming a theoretical variable. In addition to having the classification of men as being superior and women as being inferior, black woman were below these two, and feminism, inserted in the cultural and racial diversity of Latin American societies had to face all forms of oppression.

Colonial social perceptions are evident, since one still sees a society that remains prejudiced and racist. In literature, the arts and the media, black women are portrayed as uneducated, ignorant, insecure and ready to serve, most often represented as domestic workers, nannies, cleaners, cooks, funny, with wide hips and 
full breasts, different from the muse's profile of fine strokes, smooth hair and fair skin (DINIZ, 2010).

Thus, it became increasingly important to have the representativeness and instruction of black women to reach prominent positions, so that they could have the recognition of hegemonic feminism and a voice to manifest their rights. Great names in black female militancy have made history, such as the anthropologist, philosopher and intellectual Lélia Gonzalez with a PhD in philosophy from the University of São Paulo (USP), Sueli Carneiro, founder and current director of Geledés - Black Women's Institute. However, it's not enough. The movement is constantly evolving and still needs admirable figures, which are missing not due to a lack of people, but due to their invisibility (CARNEIRO, 2018).

Finally, feminism must address the different forms of oppression, it must be individualized in order to have the proper research regarding the different experiences of violence suffered by different women in different historical processes. In this sense, racism is the main factor that lowers and ridicules the black population. This is the gulf that lies between black and white women.

\subsection{THE FIGHT AGAINST RACISM AND VIOLENCE}

Black people are marginalized daily, assaulted, imprisoned, the target of jokes and treated as disposable. Genocidal practices through police violence, the extermination of children and adolescents, as well as the absence of effective public and social policies were recurrent in history. From the analysis of human conditions, we can see that survival, the struggle for essential rights and a dignified life are very difficult. In this way, it is essential to mobilize, laws, conventions and treaties that meet the demands of these people (CARNEIRO, 2018).

According to demographic data from the Institute of Applied Economic Research, or Instituto de Pesquisa Econômica Aplicada (IPEA), and the Brazilian Public Security Forum, in surveys conducted between 2011 and 2013, the North and Northeast regions of Brazil have the highest proportion of black women in their female population and, the Southern Region has the lowest proportion. They also represent 
the main group in poverty; the majority live in the regions with less access to piped water, sewage and regular garbage collection; and, are the main group active in the informal market (WERNECK; IRACI, 2017, p. 12-13).

According to the World Health Organization, violence has different natures: sexual, physical, psychological, neglect and mistreatment. However, it is possible to interpret violence as a multifaceted phenomenon, based on psychological, cultural, sociological and political aspects. Violence can be differentiated as self-inflicted, interpersonal, intrafamilial, collective and structural. Much of this violence occurs due to the heteronormative patriarchal racism embodied by sexism and Lesbian, Gay, Bisexual, Transgender, Queer (LGBTQ) phobias. However, it disproportionately affects women in the face of the combination of numerous forms of discrimination, based on systems of inequalities mainly of gender, race, ethnicity, class, orientation and sexual identity (WERNECK; IRACI, 2017, p. 13).

Between 2002 and 2013, the murders of black women in Brazil increased by $54,2 \%$ in 10 years. The homicide rate of black women nationwide is 2,25 times higher than the homicide rate of white women. From 2011 to 2013, 16 women were murdered per day, 488 per month, 5.860 per year. The victims are real black women, integrated into their communities, responsible for the subsistence and maintenance of their families (WERNECK; IRACI, 2017, p. 11-14).

According to the Ministry of Health and the Mortality Information System, of the total 1,583 of maternal deaths in $2012,60 \%$ were black women and $34 \%$ white women. Also, from 2004 to 2013, in relation to pregnant women infected with HIV, the brown race/color predominated, followed by white, which represented $41,3 \%$ and $39 \%$, respectively. In the same period, the number of deaths from aids in the mixed race/color increased. Of the people who have already felt discriminated against in the health services by a doctor or other health professional due to the reasons presented in the research, the following stood out: women 11,6\%; blacks represented $11,9 \%$, brown $11,4 \%$, and people without education or with incomplete elementary school resulted in 11,8\% (BRASIL, 2017).

By addressing discrimination in health services in the document "National Policy of Integral Health of the Black Population: A SUS Policy", the Ministry of Health 
individualizes this group reaching disproportionate results in relation to white populations. They also confirm the precariousness in the life of the black population and corroborate through their research the atrocities experienced by this group (BRASIL, 2017):

\begin{abstract}
The significant majority of black people do not have health insurance (78.8\%), and less access to health means greater exposure to risks. People with lower incomes, without access to education and in precarious housing conditions, due to lack of access to basic services, are also more exposed where the vast majority are black. The differences in the indicators for depression and smoking, according to the disaggregation by education, are also relevant, as they indicate that it is necessary to adapt policies (of communication, among others) to this most exposed public (free translation). ${ }^{6}$
\end{abstract}

According to the balance of the Ligue 180 - Women's phone line Care Center, in 2015 , of the total number of visits, 63,090 were reports of violence, of which $58,55 \%$ were committed against black women. Among the reports of violence, black women (black and brown) represent the majority of victims, followed by white women who represent 40,48\%, Asian women with 0,52\% and indigenous women with 0,45\% (BRASIL, 2015).

Considering the 2016 data, the homicide rate was 5,3 per 100,000 black women and 3,1 per 100,000 white women, the difference reaches $71 \%$ between races, that is, the homicide rate is higher among black women than among non-black women. In the 10 years of analysis between 2006 and 2016, while the country killed fewer white women, down by $8 \%$, homicides among black women increased by $15,4 \%$. The state of Goiás has the worst homicide rate of black women. Pará, has the second highest homicide rate of this group, both ranking at the top (CERQUEIRA, 2018, p. 51-52).

The emergence of these demands, globalization, the importance of viewing this group worldwide, led black women to develop an internationalist perspective of the struggle through national and international laws, treaties and conventions.

\footnotetext{
${ }^{6}$ Original text: "A expressiva maioria das pessoas negras não possui plano de saúde $(78,8 \%)$, e menor acesso à saúde significa maior exposição a riscos. Pessoas com menores rendimentos, sem acesso à educação e em condições de moradia precárias por falta de acesso a serviços básicos também se mostram mais expostas onde a grande maioria é negra. As diferenças nos indicadores de depressão e tabagismo, segundo a desagregação por educação, são também relevantes, pois indicam que é necessário adaptar políticas (de comunicação, entre outras) para este público mais exposto."
} 
In 1976 the United Nations created the United Nations Women's Development Fund, or Fundo de Desenvolvimento das Nações Unidas para a Mulher (UNIFEM), to provide technical and financial assistance to innovative programs and provide strategies that contribute to ensuring women's rights. UN Women was established in 2010, based in New York and with some regional offices around the world, following the legacy of the United Nations Development Fund for Women, in defense of the human rights for young women, black, indigenous, domestic and rural workers. The activities comprise: fostering the leadership and political participation of women, ending violence, economic empowerment, planning and global and regional norms (ONU MULHERES BRASIL, 2010).

In 1979 there was the Convention on the Elimination of All Forms of Discrimination Against Women, an international treaty approved by the United Nations General Assembly, enforced by law in Brazil. It took into consideration the international declaration of women's rights, consequently coming into effect on September 3, 1981. The Convention reiterates the principle of non-discrimination, the elimination of all forms of racism, reaffirms respect for human dignity, consolidates the importance of guaranteeing fundamental rights and highlights the equality of economic, social, political, cultural and civil rights between men and women. The international document also deals with women in poverty and maintains that women in such situations have minimal access to food, medical services, education, training and employment opportunities and other needs. Thus, this new international economic order based on equity, justice and the creation of public policies will be essential to promote equality between men and women (UN, 1979).

Other international events, important for the evolution of women's struggle, that support the idea of equality, preservation of human rights and combating violence and discrimination are: the International Convention on the Elimination of All Forms of Racial Discrimination - ICERD adopted by the United Nations General Assembly on December 21, 1965; Declaration and Program of Action of the 2nd International Conference on Human Rights in Vienna in 1993; Declaration and Plan of Action of the International Conference on Population and Development held in Cairo in 1994; Beijing 
Declaration and Platform for Action in 1995; Durban Declaration and Action Plan in 2001; Declaration of Indigenous Peoples 2007 (ONU MULHERES BRASIL, 2010).

In Brazil, as of March 2015, Law n. 13,104/2015 altered the Brazilian Penal Code to include Feminicide as one of the qualified forms of homicide, when the death of a woman stems from domestic and family violence or when provoked by contempt or discrimination against the condition of her gender, according to Article 121, item VI and $§ 2 a$ of the Penal Code (BRASIL, 1940).

According to the United Nations (UN), in 2017, out of a total of 87,000 registered homicides against women worldwide, about 50.000 (58\%) were committed by partners or family members. About 30,000 (34\%) homicides were committed by the victim's partner. Research has shown that about six women are killed every hour by someone they know. Internationally, Africa and the Americas are the regions in the world where women are most at risk of being killed by their partners or family member. In Africa, the rate is 3,2 victims per 100,000 women; in the Americas the rate is 1,6; in Oceania 1,3; and Asia 0,9. The lowest rate is in Europe with 0,7 (GELEDÉS, 2018).

The UN shows that there has been no considerable progress in combating violence against women in recent years, even with so many treaties, conventions and new laws in the signatory countries. It also emphasizes the importance of the police force and the judiciary for the prevention of crimes and the promotion of effective criminal justice. The challenge is to get governments and society to break prejudices, implement the necessary public policies and enable decent employment, health, education and quality of life for women (GELEDÉS, 2018).

\subsection{FUNDAMENTAL RIGHTS: ADVANCES AND CHALLENGES}

Fundamental rights are a historical construction born from certain circumstances, characterized by struggles in defense of new freedoms against old powers, corresponding to a certain culture. Something that is seen as a fundamental right for one State may not be for another (BOBBIO, 1992, p. 5-9).

Fundamental rights are not absolute, as they can be relativized. This is because they may conflict with each other and in this case the specific cases should 
be observed. Nevertheless, no fundamental right should be used for the practice of illicit behavior. In other words, fundamental rights may have limitations as long as they are compatible with what the constitution dictates and when the principles of reasonableness and proportionality are respected. These are unenforceable, inalienable, unavailable, indispensable, interdependent, effective, complementary, universal and indivisible (SILVA, 2006).

Title II of The Federal Constitution of 1988 entitled Fundamental Rights and Guarantees contains five chapters, subdivided into: individual and collective rights, social rights, nationality, political rights and political parties. These involve security, education, health, access to justice and cultural goods, voting rights, housing, employment, fair pay, social security, etc. (BRASIL, 1988).

The Federal Constitution of 1988 was the first in the historical process to include racism as an indefinable, unenforceable and punishable crime. Article 3, item IV, highlights the importance of the good of all without prejudice of race, origin, color, sex or any other form of discrimination. This also provided some advances in the legislation, such as the quota policy in universities, decree 4887/2003 regulating the recognition and demarcation of lands occupied by quilombolas (hinterland settlement founded by escaped slaves), Law n. 10.639/2003 that determines the teaching of AfroBrazilian history in schools and the Statute of Racial Equality (BRITO, 2018).

But it's not simply because the Federal Constitution strengthens equal rights that these rights are fully guaranteed. To ensure the rights of the black population, the Statute of Racial Equality was created, (Law n. 12,288/2010), where it states in in article 1 that the law is intended to guarantee the black population the effectiveness of equal opportunities, the defense of individual, collective and diffuse ethnic rights and the fight against discrimination and other forms of ethnic intolerance. In the same article, item III highlights gender and race inequality and accentuates the social distance between black women and other social segments. The other articles guarantee the promotion of actions, by the public authorities that ensure equal opportunities in the labor market for the black population, and allow the State to protect black women in situations of violence, guaranteeing their physical, psychological, social and legal assistance in all other sectors to ensure the well-being of the black 
population, their effective participation in society and the preservation of their human dignity (BRASIL, 2010).

If the situation is difficult for women in general, for black and indigenous women the issue is worse. In addition to being victims of machismo, they are victims of racism. There are stigmas that denounce the reality and social vulnerability to which they are submitted. These too can be called limitations that prevent black and indigenous women from achieving the fullness of fundamental rights. Some examples are: little to no schooling, lack of representation in politics, limitations regarding access to public policies, lack of basic sanitation, social security, regular employment, social inequality, salary, exploitation, violence, lack of security and quality of life (VELOSO, 2018).

Congresswoman Benedita da Silva was part of the constituent assembly of 1988 and was the first black woman to occupy a seat in the Federal Senate, she reinforces the importance of the presence of black women in politics, recognizing that the achievement is difficult, but one that cannot be given up (VELOSO, 2018):

The colonization process and slavery in Brazil resulted in racism and virtually insurmountable machismo. These are conceptions that have been placed on us, with an impact on our relationships in the labor market and our ascension in it from a social, political and economic perspective (free translation). ${ }^{7}$

The situation of black people in the labor market today still has repercussions from the time of slavery, with very little changes that have taken place after abolition and the implementation of the Aurea Law in 1888. Blacks continued to perform manual labor, in plantations, on farms, in exchange for small salaries. Submission, economic dependence and color-related prejudice remained. As immigrants arrived, unfair competition began, blacks were left with the worst activities and salaries. It would not just be a law that would change the stigma of blacks seen as merchandise, as a soulless being.

Black women are the poorest group in Brazilian society, with the most vulnerable jobs, low income and the highest unemployment rate. Consequently, it is

\footnotetext{
7 Original text: "O processo de colonização e escravidão no Brasil resultou em um racismo e em um machismo praticamente insuperáveis. São concepções que foram colocadas sobre nós, com impacto em nossas relações no mercado de trabalho e na ascensão do ponto de vista social, político e econômico."
} 
the group with the worst education rate and almost no representation in prominent or leadership positions. Through research conducted between 2004 and 2005 in metropolitan regions, it was concluded that unemployment rates are higher for black women: Belo Horizonte (23,3\%), Distrito Federal (24,6\%), Porto Alegre (25,7\%), Recife (26,8\%), Salvador (29,2\%) and São Paulo (25,1\%) (THE WOMAN, 2015).

The PED System - Employment and Unemployment Survey reported in 2010 the percentages referring to the unemployment rates for black women in metropolitan regions. We can observe that, although the rates have improved, this group continues to have great difficulties in job placement, a considerable difference compared to the white man, emphasizing the extreme inequality resulting from race and gender. The research shows the following capitals: Belo Horizonte $(12,1 \%)$, Distrito Federal (17,4\%), Fortaleza (11,5\%), Porto Alegre (14,8\%), Recife (20,6\%), Salvador $(21,6 \%)$, São Paulo (17,0\%) (NEGROS, 2011).

In view of all the data and the history of oppression in this population, UN Mulheres Brasil developed the project "Black Women Towards a Planet 50-50 in 2030" in partnership with actresses, youtubers, black bloggers and a committee with several NGOs representing the struggle of the black movement and black women. The initiative articulates and contributes to the fulfillment of issues discussed in other meetings, documents, partnerships, national action plans, which adopt as a guideline the fight against racism and the elimination of gender inequalities in the country. The intention is to support the development of public policies and demonstrations through the technical cooperation of UN Brazil with the Brazilian government, establish partnerships with companies and bring the discussion to universities (ONU MULHERES BRASIL, 2018).

In this sense, it is of paramount importance to bring these discussions to companies, universities and schools, once women are subjected to assuming an identity that is socially valued, but restricts their experiences, their ability to risk, develop their reasoning and obtain talents similar to those of men. This process makes equal competition difficult, and even more so for black women. Therefore, black women must free themselves from social and media impositions, have the support of the government and public policies, with the provision of education, quality and health, 
in order to use their intelligence, their body, their face as an expressive manifestation of freedom and equality.

\section{CONCLUSION}

The expressive feminist movement began with the movement of educated women, with professions and financial opportunities, whose purpose was to defend their political, social and economic rights. The objective of the fight involved the conquest of the right to vote and equal rights between genders, in a historical context where patriarchy, sexism and machismo were consolidated, while the figure of the woman stood out as subordinated to domestic chores, where her main concerns had to involve taking care of the home and the family.

Thus, feminism emerged to break down barriers, establish and guarantee fundamental rights. However, black women did not feel integrated into this movement, since they had different life histories from those of the privileged women who gave rise to the claims. There was a need for the dismemberment of the movement, with a strong black side, prepared to fight for their rights, but with an aggravating factor, racism, in addition to suffering gender discrimination.

The reflexes generated from the period of slavery, a time when women did not possess any human dignity, suffered constant physical and psychological violence, were judged, bought to serve and entertain, without any human dignity, were evident.

Through studies on black feminism, it can be observed that issues such as the inclusion of black women in the labor market, political representation, access to quality health, education and safety are issues that still need to be addressed and improved with the full support of the government, the UN, NGOs and the development of public policies for black women to fully exercise their rights. Furthermore, the importance of the police force and the judiciary for the prevention of crime and the promotion of effective criminal justice is emphasized. 


\section{REFERENCES}

A MULHER negra no mercado de trabalho metropolitano: inserção marcada pela dupla discriminação. Estudos e Pesquisas, v. 2, n. 14, p. 1-8, nov. 2005. Available in: https://www.dieese.org.br/estudosepesquisas/2005/estpesq14112005_mulhernegra. pdf. Access in: 2021 jan. 19.

ANDRADE, Ana Luíza Mello Santiago de. Navegando e Aprendendo. Lei Áurea. Info Escola, 2018. Available in: https://www.infoescola.com/historia-do-brasil/lei-aurea/. Access in: 2021 jan. 10.

BIROLI, Flávia. Autonomia, opressão e identidades: Autonomia, opressão e identidades: a ressignificação da experiência a ressignificação da experiência na teoria política feminista na teoria política feminista. Estudos Feministas, Florianópolis, v. 21, n. 1, p. 81-105, jan. /apr. 2013. Available in: http://www.scielo.br/pdf/ref/v21n1/05.pdf. Access in: 2021 feb. 21.

BOBBIO, Norberto. A Era dos Direitos. Rio de Janeiro: Campus, 1992.

BRASIL. Constituição da República Federativa do Brasil de 1988. 1988. Available in: http://www.planalto.gov.br/ccivil_03/constituicao/constituicaocompilado.htm. Access in: 2021 jan. 10.

BRASIL, Congresso Nacional. Assembleia Nacional Constituinte. Carta das mulheres aos constituintes entregue na sessão de 26 de março de 1987. Available in: http://www2.camara.leg.br/atividade-

legislativa/plenario/discursos/escrevendohistoria/25-anos-da-constituicao-de1988/mulher-constituinte/carta-das-mulheres-1. Access in: 2021 feb. 23.

BRASIL. Decreto-lei no 2.848, de 7 de dezembro de 1940: Código Penal. 1940. Available in: http://www.planalto.gov.br/ccivil_03/decreto-lei/Del2848compilado.htm. Access in: 2021 jan. 19.

BRASIL. Lei no 12.288, de 20 de julho de 2010: Estatuto da Igualdade Racial. Available in: http://www.planalto.gov.br/ccivil_03/_Ato20072010/2010/Lei/L12288.htm. Access in: 2021 feb. 13.

BRASIL, Ministério da Saúde. Política Nacional de Saúde Integral da População Negra: uma política do SUS. 3. ed. Brasília: Ministério da Saúde, 2017. Available in: http://bvsms.saude.gov.br/bvs/publicacoes/politica_nacional_saude_populacao_negr a_3d.pdf. Access in: 2021 jan. 19.

BRASIL, Ministério das Mulheres, da Igualdade Racial e dos Direitos Humanos. Balanço: uma década de conquistas! Ligue 180 - Central de atendimento à mulher. 2015. Available in: http://www.spm.gov.br/central-de- 
conteudos/publicacoes/publicacoes/2015/balanco180-10meses-1.pdf. Access in: 2021 feb. 14.

BRASIL, Senado Federal. Bertha Lutz. Senado Notícias, oct. 2015. Available in: https://www12.senado.leg.br/noticias/entenda-o-assunto/bertha-lutz. Access in: 2021 feb. 14.

BRITO, Débora. Negros ainda lutam por direitos básicos, 30 anos após Constituição. Portal EBC, 2018. Available in: http://agenciabrasil.ebc.com.br/direitoshumanos/noticia/2018-05/negros-ainda-lutam-por-direitos-basicos-30-anos-aposconstituicao. Access in: 2021 jan. 23.

CARNEIRO, Sueli. Enegrecer o Feminismo: A Situação da Mulher Negra na América Latina a partir de uma perspectiva de gênero. Núcleo de Estudos Afro Brasileiros e Indígenas (NEABI), Universidade Católica de Pernambuco, 2018. Available in: http://www.unicap.br/neabi/?page_id=137. Access in: 2021 jan. 19.

CERQUEIRA, Daniel (Coord.). Atlas da violência 2018. Rio de Janeiro: Instituto de Pesquisas Econômicas Aplicadas (IPEA), 2018. Available in:

http://www.ipea.gov.br/portal/images/stories/PDFs/relatorio_institucional/180604_atla s_da_violencia_2018.pdf. Access in: 2021 feb. 14.

COMISSÃO INTERAMERICANA DE DIREITOS HUMANOS, Organização dos Estados Americanos. Convenção interamericana para prevenir, punir e erradicar a violência contra a mulher, "convenção de Belém do Pará". 1994. Available in: http://www.cidh.org/Basicos/Portugues/m.Belem.do.Para.htm. Access in: 2021 jan. 23.

CORRÊA, Mariza. Do feminismo aos estudos de gênero no Brasil: um exemplo pessoal. Dossiê: feminismo em questão, questões do feminismo. Cadernos Pagu, Campinas, n. 16, p. 13-30, 2001. Available in:

http://www.scielo.br/pdf/cpa/n16/n16a02.pdf. Access in: 2021 feb. 21.

CTB, Central dos Trabalhadores e Trabalhadoras do Brasil. Entidades do Conselho Nacional dos Direitos da Mulher repudiam retirada de direitos. 2017. Available in: https://portalctb.org.br/site/component/tags/tag/conselho-nacional-dos-direitos-damulher. Access in: 2021 feb. 14.

DINIZ, Maria dos Prazeres da Silva. Feminismo negro: a busca de uma reflexão teórica particularizada. 2010. 24 f. Trabalho de Conclusão de Curso (Especialização em Psicologia Jurídica). Universidade Católica de Brasília: Brasília, DF, 2010. Available in: https://repositorio.ucb.br/jspui/bitstream/10869/886/1/AS\%20DESIGUALDADES\%20 DE\%20G\%C3\%8ANERO\%20E\%200\%20FEMINISMO\%20NEGRO\%20\%28FINAL $\% 29$.pdf. Access in: 2021 jan. 19. 
GELEDÉS, Instituto da Mulher Negra. Seis mulheres são vítimas de feminicídio a cada hora no mundo, diz ONU. 26 nov. 2018. Available in:

https://www.geledes.org.br/seis-mulheres-sao-vitimas-de-feminicidio-cada-hora-nomundo-diz-onu/. Access in: 2021 feb. 14.

GONÇALVES, Renata. Sem pão e sem rosas: do feminismo marxista impulsionado pelo Maio de 1968 ao academicismo de gênero. Colóquio Internacional Marx \& Engels, Campinas, 2009. Available in:

https://www.ifch.unicamp.br/formulario_cemarx/selecao/2009/trabalhos/sem-pao-esem-rosasdo-feminismo-marxista-impulsionado-pelo.pdf. Access in: 2021 jan. 10.

LEITE, Rosalina de Santa Cruz. Brasil Mulher e Nós Mulheres: origens da imprensa feminista brasileira. Revista Estudos Feministas, Florianópolis, v. 11, n. 1, p. 234241, 2003. Available in:

http://www.scielo.br/scielo.php?script=sci_arttext\&pid=S0104-026X2003000100014. Access in: 2021 feb. 23.

LIMA, Caroline Araújo Florêncio de. A participação das mulheres na elaboração da Constituição Federal de 1988: o lobby do batom. 2016. 18 f. Trabalho de Conclusão de Curso (Graduação em Direito) - Departamento de Direito, Universidade Federal do Rio Grande do Norte, Caicó, 2016. Available in:

http://monografias.ufrn.br:8080/jspui/bitstream/123456789/3293/1/A\%20Participa\%C 3\%A7\%C3\%A30\%20das\%20Mulheres_\%20TCC_Lima.pdf. Access in: 2021 jan. 19.

MDB - MULHER - NACIONAL. Há 33 anos, era criado o Conselho Nacional dos Direitos das Mulheres. 2018. Available in: http://mdbmulher.org.br/mdb-mulhernacional/ha-33-anos-era-criado-o-conselho-nacional-dos-direitos-das-mulheres/. Access in: 2021 feb. 14.

OLIVEIRA, Eliana de. Mulher Negra: Professora Universitária: trajetória, conflitos e identidade. Brasília: Liber, 2006.

ONU MULHERES BRASIL. Conferências Mundiais da Mulher. S/A. Available in: http://www.onumulheres.org.br/planeta5050-2030/conferencias/. Access in: 2021 feb. 21.

ONU MULHERES BRASIL. Garantir os direitos humanos das mulheres no Brasil e no mundo. 2010. Available in: http://www.onumulheres.org.br/onu-mulheres/sobre-aonu-mulheres/. Access in: 2021 feb. 23.

ONU MULHERES BRASIL. Mulheres Negras Rumo a um Planeta 50-50 em 2030. 2018. Available in: http://www.onumulheres.org.br/mulheres-negras/. Access in: 2021 dec. 12. 
ONU, Organização das Nações Unidas. Convenção sobre a eliminação de todas as formas de discriminação contra as mulheres. 1979. Available in:

http://plataformamulheres.org.pt/docs/PPDM-CEDAW-pt.pdf. Access in: 2021 jan. 19.

OS NEGROS nos mercados de trabalho metropolitanos: A população negra ainda convive com patamares de desemprego mais elevado. SISTEMA PED - Pesquisa de Emprego e Desemprego, nov. 2011. Available in:

https://www.dieese.org.br/analiseped/2011/2011pednegrosmet.pdf. Access in: 2021 feb. 14.

PEDRO, Joana Maria. A experiência com contraceptivos no Brasil: uma questão de geração. Revista Brasileira de História, São Paulo, v. 23, n. 45, p. 239-260, jul. 2003. Available in: http://www.scielo.br/scielo.php?script=sci_arttext\&pid=S010201882003000100010 . Access in: 2021 jan. 10.

RODRIGUES, Talita. Política de Saúde da Mulher comemora 25 anos: Indicadores mostram os resultados da ampliação do acesso da mulher aos serviços de saúde. Rio de Janeiro: Escola Politécnica de Saúde Joaquim Venâncio Centro Colaborador da OMS para a Educação de Técnicos em Saúde. Fundação Osvaldo Cruz (FIOCRUZ), 2016. Available in:

http://www.epsjv.fiocruz.br/noticias/reportagem/politica-de-saude-da-mulhercomemora-25-anos. Access in: 2021 jan. 23.

SARTI, Cynthia Andersen. O feminismo brasileiro desde os anos de 1970: revisitando uma trajetória. Universidade Federal de São Paulo. Estudos Feministas, Florianópolis, v. 12, n. 2, p. 35-50, 2004. Available in: http://www.scielo.br/pdf/ref/v12n2/23959.pdf. Access in: 2021 jan. 23.

SILVA, Flávia Martins André da. Direitos fundamentais. Boletim Jurídico, Uberaba/MG, v. 4, n. 176, 2006. Available in:

https://www.boletimjuridico.com.br/doutrina/artigo/1233/direitos-fundamentais. Access in: 2021 feb. 21.

VELOSO, Serena. Evento da ONU na UnB debate equidade racial e de gênero. UNB Notícias, jun. 2018. Available in: http://noticias.unb.br/publicacoes/112-extensao-ecomunidade/2346-evento-da-onu-na-unb-debate-equidade-racial-e-de-genero. Access in: 2021 jan. 19.

WELLE, Deutsche. Constituição de 1988 foi avanço nos direitos das mulheres. Carta Capital, out. 2018. Available in:

https://www.cartacapital.com.br/sociedade/constituicao-de-1988-foi-avanco-nosdireitos-das-mulheres. Access in: 2021 feb. 23.

WERNECK, Jurema; IRACI, Nilza (Coord.). A situação dos direitos humanos das mulheres negras no Brasil violências e violações. São Paulo: Geledés - Instituto da Mulher Negra e Criola - Organização de Mulheres Negras, 2017. Available in: 


\section{UFBA}

http://fopir.org.br/wp-content/uploads/2017/01/Dossie-Mulheres-Negras-.pdf. Access in: 2021 feb. 21. 